\title{
Effects in the development of children exposed to zika virus in the fetal period: an integrative review
}

\author{
Efeitos no desenvolvimento de crianças expostas ao vírus zika no período fetal: revisão integrativa \\ Efectos en el desarrollo de niños expuestos al virus del zika en el período fetal: revisión integrativa
}

\section{Gerarlene Ponte Guimarães Santos',"1 ORCID: 0000-0002-2531-5389}

Márcia Teles de Oliveira Gouveia" ORCID: 0000-0002-2401-4947

Rayla Maria Pontes Guimarães Costa ${ }^{1,11}$ ORCID: 0000-0002-1794-1419

Ana Maria Ribeiro dos Santos" ORCID: 0000-0002-5825-5335

Fernanda Valéria Silva Dantas Avelino" ORCID: 0000-0002-9835-6034

'Universidade Estadual do Piauí. Parnaíba, Piauí, Brazil. "Universidade Federal do Piauí. Teresina, Piauí, Brazil.

How to cite this article:

Santos GPG, Gouveia MTO, Costa RMPG, Santos AMR Avelino FVS. Effects in the development of children exposed to zika virus in the fetal period: an integrative review. Rev Bras Enferm. 2020;73(Suppl 4):e20190883. doi: http://dx.doi.org/10.1590/0034-7167-2019-0883

Corresponding author:

Gerarlene Ponte Guimarães Santos E-mail: gerarleneg@gmail.com

EDITOR IN CHIEF: Dulce Barbosa ASSOCIATE EDITOR: Ana Fátima Fernandes

Submission: $01-21-2020$

Approval: 07-18-2020

\section{ABSTRACT}

Objective: To know the evidence available in the literature on the effects of the zika virus in children development after fetal exposure. Methods: This is an integrative literature review with 16 scientific articles found in five databases (PubMed, LILACS, CINAHL, Web of Science and Scopus), based on the guiding question: "What are the effects in the development of children aged 0 to 6 years exposed to the zika virus in the fetal period? The STROBE statement was used for data extraction and evaluation of primary studies. Results: Exposure to the zika virus in the fetal period resulted in several congenital anomalies and/or changes in the central nervous system: microcephaly, ocular problems, neurosensorial problems, ventriculomegaly, intracranial calcification, cardiopathy, arthrogryposis, among others. Conclusion: The zika virus is neurotropic; its effect in the fetal nervous system causes irreparable damage to the child, so health professionals, especially nurses, must intensify maternal and also childcare. Descriptors: Fetus; Child, Preschool; Infant Development; Zika Virus; Central Nervous System Viral Diseases.

\section{RESUMO}

Objetivo: Conhecer as evidências disponíveis na literatura sobre os efeitos do vírus zika no desenvolvimento infantil pós-exposição no período fetal. Métodos: Trata-se de uma revisão integrativa da literatura com 16 artigos científicos encontrados em cinco bases de dados (PubMed, LILACS, CINAHL, Web of Science e Scopus), com base na pergunta norteadora: "Quais os efeitos no desenvolvimento de crianças de 0 a 6 anos de idade expostas ao vírus zika no período fetal?" Para a extração dos dados e avaliação dos estudos primários, utilizouse a declaração STROBE. Resultados: A exposição ao vírus zika no período fetal resultou em diversas anomalias congênitas e/ou alterações no sistema nervoso central: microcefalia, problemas oculares, neurosensoriais, ventriculomegalia, calcificação intracraniana, cardiopatia, artrogripose, dentre outras. Conclusão: $O$ vírus zika é neurotrópico; seu efeito no produto fetal causa danos irreparáveis à criança, portanto profissionais da saúde, em especial os enfermeiros, devem intensificar o cuidado materno-infantil.

Descritores: Feto; Criança; Desenvolvimento; Vírus Zika; Infecção Viral do SNC.

\section{RESUMEN}

Objetivo: Conocer las evidencias disponibles en la literatura sobre los efectos del virus zika en el desarrollo infantil postexposición en el período fetal. Método: Se trata de una revisión integrativa de la literatura con 16 artículos científicos encontrados en cinco bases de datos (PubMed, LILACS, CINAHL, Web of Science y Scopus), basada en la interrogación: "¿Cuáles los efectos en el desarrollo de niños de 0 a 6 años expuestos al virus zika en el período fetal?" Para extracción de datos y evaluación de estudios primarios, se utilizó la declaración STROBE. Resultados: La exposición al virus zika en el período fetal resultó en diversas anomalías congénitas y/o alteraciones en sistema nervioso central: microcefalia, problemas oculares, neurosensoriales, ventriculomegalia, calcificación intracraneal, cardiopatía, artrogriposis, etcétera. Conclusión: El virus zika es neurotrópico; su efecto en el producto fetal causa daños irreparables al niño, luego profesionales de salud, especialmente los enfermeros, deben intensificar el cuidado materno-infantil. Descriptores: Feto; Niño; Desarrollo; Virus Zika; Infección Viral del SNC. 


\section{INTRODUCTION}

The zika virus (ZIKV) is an arbovirus of the Flaviridae family, which until 2007 caused sporadic infections in regions of Africa and Asia, but, in 2015, it reached the Americas with several confirmations of acute infections, such as congenital infection, which brought much repercussion by causing microcephaly in newborns whose mothers fell ill during pregnancy ${ }^{(1)}$.

In fact, the circulation of the ZIKV from 2015 to 2016 in Brazil, and the increase in congenital malformations, triggered repercussions all over the world, which led the World Health Organization (WHO) to declare a public health emergency of international proportion, because there were no cases in the scientific literature connecting such events ${ }^{(2)}$.

The main vector transmitting this arbovirus is the Aedes aegypti, but its transmission can happen sexually. Clinical manifestations are sometimes unspecific, leading most people who get sick to show no signs or symptoms. Among the most frequent symptoms are skin rash and itching ${ }^{(3)}$.

After the Brazilian outbreak prompted congenital malformations and changes in the central nervous system in newborns whose women were affected by the zika virus during pregnancy, this finding became known as "congenital zika syndrome"(4-5).

It is known that intrauterine development is an important period for growth and development of fetal organs and tissues, so some maternal infections that occur during this period may interfere with the process. As a result, certain infections caused by etiological agents and vertical transmission such as rubella, cytomegalovirus, toxoplasmosis, herpes, and syphilis present teratogenic effects and interfere in fetal development. In addition to these diseases, when we add up zika infection, known for its teratogenic potential, the outcome is an epidemic occurrence of microcephaly and the association of other congenital malformations ${ }^{(6-7)}$.

In the meantime, health professionals, especially nurses working in maternal and also child care, by knowing the effects of the zika virus in the intrauterine period, as well as its consequences throughout child development, will be able to promote unique care in prenatal and postnatal care, with actions to promote and prevent the health of pregnant women residing in areas of ZIKV transmission; and also adequate care for newborns and children exposed to the zika virus.

\section{OBJECTIVE}

To know the evidence available in the literature about the effects of ZIKV in children development after fetal exposure.

\section{METHODS}

\section{Ethical Aspects}

Since this is an integrative review, it was used primary studies in public domain, and not be necessary submission to the Research Ethics Committee. Therefore, all ethical aspects were carefully respected.

\section{Design of the study}

This is an integrative literature review, in which five stages were applied: elaboration of the research question, search in literature for primary studies, evaluation of primary studies, analysis of collected data and review presentation ${ }^{(8)}$. This method was considered the most appropriate to explore and define the existing literature available from scientific sources.

The research question prepared for the integrative literature review was: "What are the effects in the development of children 0 to 6 years old exposed to the zika virus in the fetal period? The PICo strategy was used to construct the guiding question, being "P" (population or problem) - children aged 0 to 6 years; "I" (situation of interest) - effect in child development; "Co" (context) - exposure to the zika virus in the fetal period.

The Guideline Strengthening the Reporting of Observational Studies in Epidemiology (STROBE) was used for data extraction and evaluation of selected primary studies, which refers to a checklist containing 22 items presenting recommendations on the data that should be described in observational studies ${ }^{(9)}$.

\section{Sample and collection period}

The following databases were searched for primary studies: PUBMED (National Library of Medicine and National Institutes of Health), LILACS (Latin American and Caribbean Health Sciences Literature) via BVS (Virtual Health Library), CINAHL (Cumulative Index to Nursing and Allied Health Literature), Web of Science e SCOPUS. The controlled descriptors were defined according to each database using the Medical Subject Headings - (MeSH), Descriptors in Health Sciences - (DeCS), CINAHL Headings and also defining the keywords.

The descriptors and keywords used in PUBMED, Web of Science e SCOPUS were: Child, Preschool; Infant Health; Infant, Newborn; Child Development; Neurodevelopment; Motor Skills; Congenital, Hereditary, and Neonatal Diseases and Abnormalities; Neurodevelopmental Disorders; Dengue; Chikungunya Fever; Zika Virus Infection (MESH) and Children; Child; Baby Health; Health of Newborn Infants; Health of the Newborn Infant; Newborn Infant Health; Neonate; Newborns; Development, Infant; Motor Skills; Child Mental Disorders; Mental Disorders Diagnosed in Childhood; Break-bone Fever; Breakbone Fever; Classical Dengue; Classical Dengue Fever; Dengue Fever; Chikungunya Virus Infection; Fever Zika; ZikVInfection; Zika Fever; Zika Virus Disease (keywords).

As descriptors in LILACS via BVS, were used: Preschool children; Child, Preschool; Newborn; Breastfeeding child; Infant; Child Development; Neurodevelopmental Disorders; Congenital, Hereditary, and Neonatal Diseases and Abnormalities; Motor Skills; Dengue; Chikungunya Fever; Zika Virus (DeCS).

There were also used keywords in LILACS via VHL: Preschool Child; Preschool Children; Preschools; Newborn Child; Breastfeeding child; Newborn; Neonate; Newborn; Breastfeeding child; Preschool Development; Neur* Development Disorders; Neurdevelopment Disorder; Developmental Disorders Neur*; Neonatal Diseases and Abnormalities; Motor Skill; Skill, Motor; Breakbone Fever; Dengue Fever; Dengue Virus Infection; Chikungunya Virus Infection; Zika Fever Virus; ZIKV; Zikavirus.

In CINAHL: Child, Preschool /PF; Infant Health; Infant, Newborn; Child Development; Motor Skills; Neurodevelopmental Disorders; Dengue; Chikungunya; Fever Zika Virus Infection (CINAHL Headings); Baby Health; Health of Newborn Infants; Health of the Newborn Infant; Newborn Infant Health; Child Development; Motor Skills Disorders; Dengue Fever; Fever, Dengue; Chikungunya Virus Infection; ZIKV; Zika; ZikaV (synonym/entry term). 
Therefore, after the search for descriptors and keywords, it was developed the database search strategy, using Boolean operators "OR" or/and "AND" to separate descriptors and keywords. After selecting the databases and defining the search strategy, the selection of primary studies began, which took place between the months of September and November 2019. Finally, the sample consisted of 16 articles eligible for this review.

\section{Inclusion and exclusion criteria}

As inclusion criteria, it was defined the primary studies whose authors investigated the effects of the zika virus in children's development after exposure in the fetal period, without applying filters regarding language, textual integrality of the articles and period limitation. The exclusion criteria were non-observational studies, case reports, editorial letters, theses, and dissertations.

Based on the results found, the studies were pre-selected at each base by reading titles and abstracts. The studies that achieved eligibility were selected and exported to Endnote online. Filters were then applied to duplicate studies, books, dissertations, theses, and other studies that did not meet the inclusion criteria.

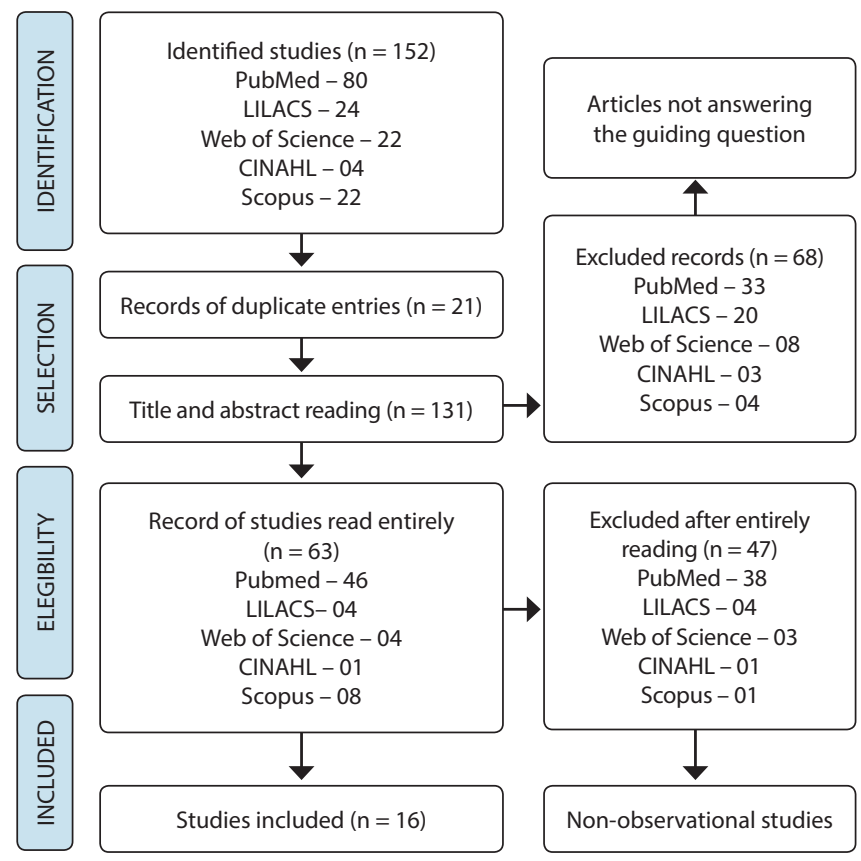

Figure 1 - flowchart of primary studies selection, adapted from PRISMA, Brazil, 2019

Subsequently, the primary studies were read in their entirety. At that stage, the study design was verified, including the observational, cohort, case-control, and cross-sectional studies. The steps described were performed independently by two reviewers. After applying the inclusion and exclusion criteria, it was obtained a sample of 16 studies, which are presented in Figure 1, in accordance with the Preferred Reporting Items for Systematic Reviews and Meta-Analyses (PRISMA) ${ }^{(10)}$.

\section{Analysis of Results}

The data analysis was performed in a descriptive manner. The selected studies were evaluated through STROBE, in which every item received a score of 0 or 1 and was later transformed into a percentage. It was considered of good quality the primary studies with a percentage higher than $40 \%$.

Then, two charts were built. The first shows data from the publication: authors and year, title, type of study and percentage of STROBE. The second chart provides the following information: authors and year, objective, location of the study, sample, and main results. Thus, the results were presented according to the outcomes revealed in the studies.

\section{RESULTS}

Of the 16 studies selected, all presented good quality (> 40\%) in relation to the items on the STROBE checklist, according to Chart 1.

All primary studies have been published in English. Regarding the countries of origin of those studies, we observed that $75 \%$ were carried out in Brazil ( $n=12) ; 6.2 \%$ in Colombia $(n=1) ; 6.2 \%$ in French Polynesia $(n=1) ; 6.2 \%$ in French Guiana, Guadeloupe and Martinique ( $n=1)$; and $6.2 \%$, carried out concomitantly in two countries: Brazil and Australia $(n=1)$. As to the publication period, it was observed that nine studies (56.2\%) were published in 2018; six in 2019 (37.5\%); and one in 2016 (6,2\%).

The results presented in this review show the effects in child development in prenatal exposure to ZIKV. The evidence found revealed neurological abnormalities and/or congenital malformations in the 16 studies.

Thus, in ten studies (62.5\%) was observed the presence of microcephaly; in seven (43.7\%), ocular alterations such as nystagmus or visual impairment; in four (25\%), ventriculomegaly; in three (18.7\%), subcortical calcifications, alterations in fine motor development, arthrogryposis; in two (12.5\%), cortical development malformation, cerebral atrophy, cerebral palsy with microcephaly, changes in motor and cognitive development and hearing loss; and in one (6.25\%), convulsions, restless movements at 12 months without microcephaly, changes in sleep pattern, severe hypertonia and heart malformation ${ }^{(5,11-25)}$.

Chart 2 shows the authorship, year, objectives of the studies, place of origin, sample and main results achieved.

Chart 1 - Characterization of primary studies included in the integrative review, regarding the quality of STROBE, Brazil, 2019

\begin{tabular}{|c|l|c|c|}
\hline \multicolumn{1}{|c|}{ Author, (year) } & Title & Type of Study & STROBE \\
\hline Lage et al., (2019)(11) & $\begin{array}{l}\text { Clinical, Neuroimaging, and Neurophysiological Findings in Children with Microcephaly } \\
\text { Related to Congenital Zika Virus Infection }\end{array}$ & $\begin{array}{c}\text { Transversal } \\
\text { Retrospective }\end{array}$ & $63,3 \%$ \\
\hline Rocha et al., (2019)(12) & Virus Infection and Microcephaly: A Case-Control Study in Brazil & $\begin{array}{c}\text { Exploratory case } \\
\text { control }\end{array}$ & $\begin{array}{c}90,9 \% \\
\text { To be continued }\end{array}$ \\
\hline
\end{tabular}


Chart 1 (concluded)

\begin{tabular}{|c|c|c|c|}
\hline Author, (year) & Title & Type of Study & STROBE \\
\hline Trigueiro et al., (2019) $)^{(13)}$ & $\begin{array}{l}\text { Correlation between Cephalic Circumference at Birth and Ocular Alterations in Patients with } \\
\text { Microcephaly Potentially Associated with Zika Virus Infection }\end{array}$ & Cohort & $63,6 \%$ \\
\hline Portnoi et al., (2019) ${ }^{(14)}$ & $\begin{array}{l}\text { Alterations in Visual Acuity and Visual Development in Infants 1-24 Months Old either } \\
\text { Exposed to or Infected by Zika Virus During Gestation, with and without Microcephaly }\end{array}$ & Cohort & $59 \%$ \\
\hline Einspieler et al., (2019) $)^{(15)}$ & $\begin{array}{l}\text { Association of Infants Exposed to Prenatal Zika Virus Infection With Their Clinical, Neurologic, } \\
\text { and Developmental Status Evaluated via the General Movement Assessment Tool }\end{array}$ & Cohort & $95,4 \%$ \\
\hline Ventura et al., (2019)(16) & $\begin{array}{l}\text { Early Gross Motor Development Among Brazilian Children with Microcephaly Born Right } \\
\text { After Zika Virus Infection Outbreak }\end{array}$ & $\begin{array}{l}\text { Prospective } \\
\text { observation }\end{array}$ & $63,6 \%$ \\
\hline Cortes et al., $(2018)^{(17)}$ & $\begin{array}{l}\text { Clinical Assessment and Brain Findings in a Cohort of Mothers, Fetuses and Infants Infected } \\
\text { with ZIKA Virus }\end{array}$ & $\begin{array}{l}\text { Longitudinal } \\
\text { Cohort }\end{array}$ & $72,7 \%$ \\
\hline Subissi et al., (2018) $)^{(5)}$ & $\begin{array}{l}\text { Zika Virus Infection during Pregnancy and Effects on Early Childhood Development, French } \\
\text { Polynesia, 2013-2016 }\end{array}$ & Case-control study & $77,2 \%$ \\
\hline Tsui et al., $(2018)^{(18)}$ & Eye Findings in Infants With Suspected or Confirmed Antenatal Zika Virus Exposure. & Cohort & $77,2 \%$ \\
\hline Zin et al., (2018) ${ }^{(19)}$ & Visual Function in Infants with Antenatal Zika Virus Exposure & Transversal & $59,0 \%$ \\
\hline Hoen et al., (2018) $(20)$ & Pregnancy Outcomes after ZIKV Infection in French Territories in the Americas & $\begin{array}{l}\text { Prospectivo } \\
\text { Cohort }\end{array}$ & $66,6 \%$ \\
\hline Pinato et al., $(2018)^{(21)}$ & Sleep Findings in Brazilian Children with Congenital Zika Syndrome & Cohort & $59,0 \%$ \\
\hline França et al., (2018)(22) & $\begin{array}{l}\text { Growth and Development of Children with Microcephaly Associated with Congenital Zika } \\
\text { Virus Syndrome in Brazil }\end{array}$ & $\begin{array}{l}\text { Observational, } \\
\text { analytical and } \\
\text { transversal }\end{array}$ & $77,2 \%$ \\
\hline Wheeler et al., (2018) ${ }^{(23)}$ & Skills Attained by Infants with Congenital Zika Syndrome: Pilot Data from Brazil & Cohort & $45,4 \%$ \\
\hline Orofino et al., (2018) & Cardiac Findings in Infants within Utero Exposure to Zika Virus - a Cross Sectional Study & Transversal & $68,1 \%$ \\
\hline Kikuti et al., (2016) & $\begin{array}{l}\text { Congenital Brain Abnormalities during a Zika Virus Epidemic in Salvador, Brazil, April } 2015 \text { to } \\
\text { July } 2016\end{array}$ & Cohort & $45,4 \%$ \\
\hline
\end{tabular}

Chart 2 - Characterization of primary studies included in the review, according to the profile of children born whose mothers had zika infection, Brazil, 2019

\begin{tabular}{|c|c|c|c|c|}
\hline Author (year) & Objective & Local & Sample & Main results \\
\hline $\begin{array}{l}\text { Lage et al., } \\
(2019)^{(11)}\end{array}$ & $\begin{array}{l}\text { Describe the clinical, } \\
\text { neuroimaging and } \\
\text { neurophysiological findings } \\
\text { of children with congenital } \\
\text { microcephaly diagnosed at } \\
\text { birth, associated with ZIKV } \\
\text { congenital infection. }\end{array}$ & Brazil & $\begin{array}{l}102 \text { newborns } \\
\text { with } \\
\text { microcephaly }\end{array}$ & $\begin{array}{l}\text { Severe microcephaly }(54.9 \%) \text {, cerebral malformations }(100 \%) \text {; } \\
\text { cerebral atrophy }(92.1 \%), \text { ventriculomegaly }(92.1 \%) \text {, malformation } \\
\text { of cortical development }(85.1 \%) \text { and subcortical calcifications } \\
(80.2 \%) \text {; abnormalities in neurological examinations }(97.0 \%) \text {, } \\
\text { seizures (56.3\%) and arthrogryposis (10.8\%); hearing loss (17.3\%) } \\
\text { and visual impairment (14.1\%) of breastfeeding infants. }\end{array}$ \\
\hline $\begin{array}{l}\text { Rocha et al., } \\
(2019)^{(12)}\end{array}$ & $\begin{array}{l}\text { Identify factors associated with } \\
\text { the diagnosis of microcephaly } \\
\text { in newborns, including zika } \\
\text { virus infection. }\end{array}$ & Brazil & $\begin{array}{l}58 \text { children with } \\
\text { microcephaly } \\
\text { and } 116 \\
\text { controls }\end{array}$ & $\begin{array}{l}\text { The chance of having a newborn with microcephaly was } 14 \text { times } \\
\text { higher among mothers who had infection with zika virus }(p< \\
0,001) \text {. }\end{array}$ \\
\hline $\begin{array}{l}\text { Trigueiro et } \\
\text { al., (2019) }\end{array}$ & $\begin{array}{l}\text { Describe the profile of children } \\
\text { with microcephaly, whose } \\
\text { mothers had zika infection } \\
\text { during pregnancy. }\end{array}$ & Brazil & $\begin{array}{l}20 \text { newborns } \\
\text { with } \\
\text { microcephaly }\end{array}$ & $\begin{array}{l}\text { Eye alterations }(70 \%) \text { and macular atrophy ( } 30 \%) \text {. Eye alterations } \\
\text { varied from normal to paleness and hypoplasia of the optic nerve, } \\
\text { dispersion of the pigment epithelium of the retina in the macular } \\
\text { region and chorioretinal macular atrophy. }\end{array}$ \\
\hline $\begin{array}{l}\text { Portnoi et al., } \\
(2019)^{(14)}\end{array}$ & $\begin{array}{l}\text { Assess visual acuity and } \\
\text { development of visual acuity } \\
\text { in children exposed to the zika } \\
\text { virus in pregnancy. }\end{array}$ & Brazil & $\begin{array}{l}23 \text { exposed } \\
\text { children and } \\
24 \text { infected } \\
\text { children }\end{array}$ & $\begin{array}{l}\text { Abnormal visual acuity was found in } 5 \text { out of } 24 \text { children infected } \\
\text { with ZIKV. Of the four children with microcephaly, two had } \\
\text { loss of visual acuity and one had abnormal result in the retina } \\
\text { examination. }\end{array}$ \\
\hline 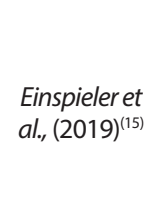 & $\begin{array}{l}\text { Perform general movement } \\
\text { assessment among children } \\
\text { from } 9 \text { to } 20 \text { weeks of age; and } \\
\text { assess neurological development } \\
\text { at } 12 \text { months of age in children } \\
\text { exposed to prenatal care to ZIKV } \\
\text { and in paired controls. }\end{array}$ & $\begin{array}{c}\text { Brazil/ } \\
\text { Australia }\end{array}$ & $\begin{array}{l}111 \text { exposed } \\
\text { children and } \\
333 \text { control } \\
\text { children }\end{array}$ & $\begin{array}{l}\text { Of the exposed children, } 50.4 \% \text { had abnormal neurological } \\
\text { development and no microcephaly. Of the ten children exposed } \\
\text { to ZIKV without microcephaly at } 12 \text { months of age, seven had no } \\
\text { restless movements. Children with microcephaly had bilateral } \\
\text { spastic cerebral palsy; none had normal movements. }\end{array}$ \\
\hline
\end{tabular}




\begin{tabular}{|c|c|c|c|c|}
\hline Author (year) & Objective & Local & Sample & Main results \\
\hline $\begin{array}{l}\text { Ventura et al., } \\
(2019)^{(16)}\end{array}$ & $\begin{array}{l}\text { To evaluate the gross motor } \\
\text { development of children with } \\
\text { supposedly congenital zika } \\
\text { virus infection in the first two } \\
\text { years of life. }\end{array}$ & Brazil & $\begin{array}{l}77 \text { children } \\
\text { (ages } 11,18 \text { and } \\
24 \text { months) }\end{array}$ & $\begin{array}{l}\text { All children evaluated in the study showed clinical diagnosis of } \\
\text { cerebral palsy (PC) at } 2 \text { years of age. Seventy-four }(96.1 \%) \text { showed } \\
\text { motor skills similar to children aged } 4 \text { months or less, and } 73(94.8 \%) \\
\text { children had quadriplegia. No significant difference ( } p=0.076) \text { was } \\
\text { found between } 18 \text { and } 24 \text { months. }\end{array}$ \\
\hline $\begin{array}{l}\text { Cortes et al., } \\
(2018)^{(17)}\end{array}$ & $\begin{array}{l}\text { To evaluate the prevalence of } \\
\text { microcephaly and the frequency } \\
\text { of abnormalities based on } \\
\text { imaging examinations; and to } \\
\text { obtain additional information } \\
\text { from placental and fetal } \\
\text { histopathological evaluations } \\
\text { and postnatal clinical evaluations. }\end{array}$ & Colombia & 12 newborns & $\begin{array}{l}\text { The main abnormalities found in the MRI examination were } \\
(11 / 12 ; 91.7 \%) \text { calcifications and ventriculomegaly, abnormalities } \\
\text { of the corpus callosum }(12 / 12 ; 100 \%) \text {, cortical malformations } \\
\text { ( } 8 / 9 ; 89 \%) \text {. At birth, most of the affected neonates ( } 55.6 \%-77.8 \%) \\
\text { presented measurements of PC }>3 \text { and standard deviation below } \\
\text { medium. }\end{array}$ \\
\hline $\begin{array}{l}\text { Subissiet al., } \\
(2018)^{(5)}\end{array}$ & $\begin{array}{l}\text { Determine the temporal } \\
\text { association of a cluster of } \\
\text { congenital defects with zika } \\
\text { virus infection }\end{array}$ & $\begin{array}{l}\text { French } \\
\text { Polynesia }\end{array}$ & $\begin{array}{l}21 \text { cases and } \\
102 \text { controls }\end{array}$ & $\begin{array}{l}\text { Microcephaly ( } 33.3 \%) \text { and brain stem dysfunction characterized } \\
\text { by inability to suck and swallow }(23.8 \%) \text {, among other congenital } \\
\text { defects in the CNS }(42.8 \%) \text {. Ventriculomegaly }(28 \%) \text { and } \\
\text { arthrogryposis }(14,2 \%) \text {. }\end{array}$ \\
\hline $\begin{array}{l}\text { Tsui et al., } \\
(2018)^{(18)}\end{array}$ & $\begin{array}{l}\text { Characterize the ophthalmic } \\
\text { manifestations of confirmed or } \\
\text { suspected prenatal exposure to } \\
\text { zika virus (ZIKV) }\end{array}$ & Brazil & $\begin{array}{c}224 \\
\text { breastfeeding } \\
\text { infants }\end{array}$ & $\begin{array}{l}\text { Abnormalities in the CNS ( } 40.2 \%) \text {, including microcephaly ( } 27.7 \%) \text {. } \\
\text { Eye abnormalities were found in } 49 \text { of } 90 \text { infants }(54.4 \%) \text { and } \\
\text { correlated with the presence of CNS findings (odds ratio } 14.9 ; 95 \% \\
\text { Cl: } 7.3-30.3 ; p<0.0001) \text {. Of the children without microcephaly or } \\
\text { other abnormalities in the CNS, } 3.7 \% \text { had ocular abnormalities. }\end{array}$ \\
\hline $\begin{array}{l}\text { Zinet al., } \\
(2018)^{(19)}\end{array}$ & $\begin{array}{l}\text { To evaluate visual function } \\
\text { in breastfeeding infants with } \\
\text { confirmed or suspected prenatal } \\
\text { exposure to infecction by } \\
\text { ZIKV during the outbreak of zika. }\end{array}$ & Brazil & $\begin{array}{l}173 \text { children } \\
\text { with } \\
\text { microcephaly }\end{array}$ & $\begin{array}{l}\text { Of the children evaluated, } 49.1 \% \text { presented abnormal findings } \\
\text { in the CNS; } 35.8 \% \text {, microcephaly; and } 13.3 \% \text {, other abnormalities } \\
\text { in the CNS without microcephaly. Abnormal visual function was } \\
\text { present in } 30 \% \text { of children; eye alterations in } 26 \% \text {; nystagmus in } \\
15,6 \% \text {. }\end{array}$ \\
\hline $\begin{array}{l}\text { Hoen et al., } \\
(2018)^{(20)}\end{array}$ & $\begin{array}{l}\text { Estimate the risk among } \\
\text { pregnant women with } \\
\text { symptomatic ZIKV infection. }\end{array}$ & $\begin{array}{l}\text { French } \\
\text { Guiana, } \\
\text { Guadeloupe } \\
\text { and } \\
\text { Martinique }\end{array}$ & $\begin{array}{l}546 \text { pregnant } \\
\text { women with } \\
\text { ZIKV }\end{array}$ & $\begin{array}{l}\text { Neurological and ocular abnormalities associated with ZIKV infection } \\
\text { were observed in } 39 \text { newborns ( } 7.0 \% ; \mathrm{Cl}: 95 \%, 5.0 \text { to } 9.5) \text {. Microcephaly } \\
\text { was detected in } 32 \text { fetuses and newborns (5.8\%): in 1.6\%, it was } \\
\text { severe; in } 1.6 \% \text {, it was moderately disproportionate; and in } 2.5 \% \text {, it } \\
\text { was moderately proportional. Severe microcephaly or other brain } \\
\text { abnormalities were observed in } 17 \text { fetuses and newborns (3,1\%). }\end{array}$ \\
\hline $\begin{array}{l}\text { Pinato et al., } \\
(2018)^{(21)}\end{array}$ & $\begin{array}{l}\text { Investigate the sleep } \\
\text { characteristics of newborns/ } \\
\text { breastfeeding infants ( } 88 \\
\text { with CZS and } 48 \text { with healthy } \\
\text { development, age, and paired } \\
\text { sex) using the Child Sleep } \\
\text { Questionnaire. }\end{array}$ & Brazil & $\begin{array}{l}136 \text { newborns } \\
\text { and infants }\end{array}$ & $\begin{array}{l}\text { Of children with CZS, } 34.1 \% \text { had poor sleep; } 3.5 \% \text { had more than } \\
\text { three night awakenings; } 15 \% \text { were awake at night for more than } \\
\text { an hour; and } 24 \% \text { had less than nine hours of total sleep time. The } \\
\text { average time to start sleeping at night was later for the CZS group. } \\
\text { When the duration of night sleep was analyzed, } 51 \% \text { of the CZS } \\
\text { group and } 20.8 \% \text { of the healthy group had less than nine hours of } \\
\text { sleep. }\end{array}$ \\
\hline $\begin{array}{l}\text { França et al., } \\
\quad(2018)^{(22)}\end{array}$ & $\begin{array}{l}\text { To evaluate the growth and } \\
\text { development of children with } \\
\text { CZS compared to healthy } \\
\text { children. }\end{array}$ & Brazil & $\begin{array}{l}\text { Children CZS } \\
\quad(n=08) / \\
\text { Children with } \\
\text { no CZS }(n=16)\end{array}$ & $\begin{array}{l}\text { The average growth rate was lower in the group of children with } \\
\text { CZS }(p<0.05) \text { in weight and cephalic perimeter measurements at } \\
20.5 \text { months of age. There was a significant difference }(p=0.000) \\
\text { in cognitive and motor performance between the groups. }\end{array}$ \\
\hline $\begin{array}{l}\text { Wheeler AC, } \\
(2018)^{(23)}\end{array}$ & $\begin{array}{l}\text { Describe the developmental } \\
\text { profile of breastfeeding infants } \\
\text { with CZS in skills achieved at } \\
16 \text { months of age. }\end{array}$ & Brazil & $\begin{array}{l}52 \text { children with } \\
\text { CZS }\end{array}$ & $\begin{array}{l}\text { Of the children, } 81 \% \text { had severe hypertonia and multiple contractures; } \\
83.8 \% \text { had visual impairment, of which } 41.9 \% \text { had severe impairment; } \\
17 \% \text { had hearing impairment; } 11 \% \text { had arthrogryposis. No child } \\
\text { showed age-appropriate motor skills. Only one ( } 1.9 \% \text { ) was able to sit } \\
\text { without support or walk without support. About } 50 \% \text { did not hold a } \\
\text { small object in their hands and was unable to drink liquid in a glass. }\end{array}$ \\
\hline $\begin{array}{l}\text { Orofino et al., } \\
(2018)^{(24)}\end{array}$ & $\begin{array}{l}\text { Report echocardiographic } \\
\text { (ECO) findings in infants with } \\
\text { laboratory confirmed prenatal } \\
\text { exposure to ZIKV. }\end{array}$ & Brazil & $\begin{array}{l}120 \text { children } \\
\text { with prenatal } \\
\text { exposure to } \\
\text { ZIKV }\end{array}$ & $\begin{array}{l}\text { Of the children, } 40 \% \text { presented alterations observed in } \\
\text { echocardiography, while } 10.8 \% \text { had heart defects such as interatrial } \\
\text { communication, ventricular interatrial communication, and } \\
\text { persistence of the ductus arteriosus. The frequency of heart defects } \\
\text { was observed in newborns that were exposed in the } 2 \text { nd trimester } \\
\text { of pregnancy or in those in which the image examination of the } \\
\text { (CNS) was altered in the postnatal period or in premature. }\end{array}$ \\
\hline $\begin{array}{l}\text { Kikutiet al., } \\
(2016)^{(25)}\end{array}$ & $\begin{array}{l}\text { Describe clinical and } \\
\text { epidemiological aspects of the } \\
\text { outbreak of congenital brain } \\
\text { abnormalities; and assess the } \\
\text { accuracy of different screening } \\
\text { criteria of the cephalic perimeter }\end{array}$ & Brazil & 365 newborns & $\begin{array}{l}\text { Congenital brain abnormalities ( } 45.5 \%) \text {, intracranial calcifications } \\
\text { and ventriculomegaly }(86,1 \%) \text {. }\end{array}$ \\
\hline
\end{tabular}




\section{DISCUSSION}

The primary studies grouped in this review showed evidence of exposure to ZIKV in the fetal period and the post exposure effects in newborns (NBs) and breastfeeding children. Neurological abnormalities and/or congenital malformations were present in all studies ${ }^{(5,11-25)}$. Microcephaly $(62.8 \%)^{(5,11-20)}$ was predominant, however other studies have reported the occurrence of alterations in the central nervous system and multiple malformations ${ }^{(12,21-25)}$.

The increasing number of births of microcephalic newborns and exposure to ZIKV during pregnancy were the first evidence observed in the scientific literature that occurred in the maternalinfant outcome. For Brady et al.(26) and Noronha et al. ${ }^{(27)}$, there was a temporal association between the increase in cases of microcephaly and the Zika epidemic; the infection that occurred in the first two quarters is considered to be of greater risk for pregnant women living in areas with ZIKV presence. In the study by Rocha et al. ${ }^{(12)}$, microcephaly in newborns was 14 times higher among those exposed to prenatal ZIKV. In another study, with 224 children, 90 (40.2\%) presented changes in the central nervous system, such as microcephaly ${ }^{(18)}$.

Moreover, ZIKV is teratogenic, and besides microcephaly, 12 studies (75\%) have found other brain abnormalities compromising neural development ${ }^{(5,11,15-25)}$. In this context, ventriculomegaly $y^{(5,11,17,25)}$ was found in $25 \%$ of studies; subcortical calcifications ${ }^{(11,17,25)}$, in 18.7\%; and malformation of cortical development and cerebral atrophy ${ }^{(11,17)}$, in $12.5 \%$. Other anomalies identified in smaller proportion were corpus callosum agenesis and lissencephaly ${ }^{(11,17,25)}$.

In addition, it was revealed the presence of brain abnormalities in newborns with or without microcephaly. Other neurological manifestations were also discovered, such as seizures and restless movements at 12 months of age ${ }^{(11,15)}$. It was observed that the harmfulness of ZIKV infection to the fetal product was not restricted to congenital microcephaly.

Zika virus neurotropism was found in viral proteins in glial cells, endothelial cells, and brain tissue, and also detected in localized lesions in the white matter of the brain. These findings contribute to the understanding of the interaction between the virus and the host cells ${ }^{(27)}$.

Because it is neurotropic and has a predilection for the central nervous system, the ZIKV is able to remain for a long time in that area, causing neurotoxicity. Thus, although the pregnant woman no longer presents any symptoms, the ZIKV continues to cause damage to the fetal central nervous system. The presence of ZIKV was detected in the fetal brain, placenta, membrane and umbilical cord, showing high viral load ${ }^{(28-29)}$.

Only two studies $(12.5 \%)(11,23)$ showed signs suggestive of sensorineural changes: in both, nearly $17 \%$ of children had hearing loss. Other evidence in this review was visual acuity abnormalities, reported in eight studies $(43.7 \%)^{(11,13-14,18-19,23)}$. In a cohort of 173 children with microcephaly, $30 \%$ presented abnormalities in vision; of these, $50 \%$ had nystagmus ${ }^{(19)}$. In another study with 90 children, 49 (54.4\%) had abnormalities of vision. Therefore, correlating the alterations in the central nervous system and ophthalmic manifestations, children exposed to ZIKV during pregnancy and who did not have microcephaly, had ophthalmic abnormalities to a lesser extent $(n=5 ; 3,7 \%)^{(18)}$.
Abnormalities in the visual field are present in children exposed to ZIKV in the fetal period, even in those who did not present microcephaly and/or central nervous system alterations. The most common abnormalities reported in other studies were chorioretinal atrophy, abnormalities in the optic nerve (hypoplasia and cupping of the optic disc), foveal reflex, macular neuroretinal atrophy. In this study, there were not found visual field changes in a newborn without microcephaly ${ }^{(30)}$.

From the studies observed in this review, it was understood that children born to mothers exposed to the ZIKV, whether or not they have microcephaly, should receive a visual field evaluation, and be attended for a long period. Then, arises the importance of early diagnosis and periodic follow-up of these children, which should be prioritized by the department of public health.

Thus, ophthalmic alterations, joint contractures and excessive scalp skin were reported in a study associated with congenital ZIKV infection ${ }^{(29)}$. In this review, congenital heart disease was related to exposure to ZIKV in the fetal period, presented in 14\% of premature newborns, in $10 \%$ of breastfeeding children whose mothers were exposed to ZIKV in the second trimester of pregnancy, and in $11 \%$ of breastfeeding children who had results from imaging exams with alterations in the central nervous system. None of the newborns had severe heart defects ${ }^{(24)}$.

In this sense, congenital heart disease was associated with CZS, found in a lower proportion (6.25\%) in this review. Other studies also point to the birth of newborns with arthrogryposis ${ }^{(5,11,23)}$, causing damages to the motor development of these children.

Certainly, children exposed to the ZIKV in the prenatal period present, in the short or long term, changes in motor and/or cognitive development, even those without evidence of microcephaly.

Regarding the evaluation of gross motor development in 80 children diagnosed with CZS, all have received clinical diagnosis of cerebral palsy ${ }^{(16)}$. In another study it was found a delay in cognitive development and extremely low motor development ${ }^{(22)}$. Still in the study from France et al. ${ }^{(22)}$, children not exposed to ZIKV revealed normal cognitive and motor development.

The fine motor development of infants with CZS at 16 months was compromised as they showed no social interest and were not able to drink liquids in a cup held by the caregiver. In this study, sleep was not considered a problem for most breastfeeding children, however none of them showed age appropriate skills ${ }^{(23)}$.

Following the sleep characteristics of 136 newborns and breastfeeding children, it was observed that $34.1 \%$ of children with CZS had poor sleep, 3.5\% woke up more than three times at night, $15 \%$ were up more than one hour at night and $24 \%$ had less than nine hours of total sleep time ${ }^{(21)}$.

In this context, maternal-fetal infection by ZIKV is a public health problem. The exposure of the fetus to the zika virus can happen in any gestational period, with the potential to cause serious problems for childhood neurodevelopment. The findings uncovered in this study point to the need for early intervention in childcare. Children with CZS need special lifetime health care, and careful surveillance is required for potentially affected neonates and their families ${ }^{(11,23)}$. Monitoring by health professionals, doctors and nurses from prenatal care, child growth and development is paramount for the prevention and reduction of ZIKV damage. 


\section{Study limitations}

The application of STROBE has limited the selection of studies, since only primaries studies observations were selected, while others, which could offer additional information, were excluded because they did not fit the instrument.

\section{Contributions to Nursing, Health or Public Policy}

The results presented in this review contribute to better maternal and child health care. In territories with circulation of Aedes aegypti mosquitoes and zika virus, it is necessary that health professionals know the effects of ZIKV on the fetal product and child development. Thus, nurses and other professionals working in Primary Health Care, through their knowledge of this information, can contribute to the promotion and prevention of maternal and child health.

\section{CONCLUSION}

In this integrative review were found surveys that highlighted the effect of the zika virus on the fetal product and the irreparable damage that occurred in childhood development. The studies evaluated newborns and breastfeeding children in which were found congenital malformations and other CNS alterations, especially microcephaly, cerebral atrophy, ventriculomegaly, subcortical calcifications, nystagmus, cerebral palsy, altered sleep pattern, hearing and visual impairment, congenital heart diseases and arthrogryposis.

Considering that there are many countries with circulation of Aedes aegypti and/or Aedes albopictus mosquitoes, actions to control these vectors must be intensified, as well as the development of health promotion actions for couples who wish to become pregnant and pregnant women, alerting them to the harm caused by the ZIKV.

Knowing that the first years of a child's life are important for neurodevelopment, the evaluation of acquired skills allows health professionals to identify delays in child development, which may be affected by several risk factors, such as prenatal exposure to the ZIKV. Timely identification of developmental delay and early positively stimulation positively favor neuropsychomotor development.

Health professionals, especially nurses, are recommended to intensify maternal and childcare, promoting the health of the dyad, from gestation, through birth, to the 24 months of life of the child. The children's health booklet is an important working tool for professionals to carry out an integral monitoring, so as to identify early changes in the child's growth and development.

\section{REFERENCES}

1. Marinho PS, Cunha AJ, Amim Jr J, Prata-Barbosa A. A review of selected Arboviruses during pregnancy. Matern Health Neonatol Perinatol. 2017;3:17. doi: 10.1186/s40748-017-0054-0

2. Musso D, Ko Al, Baud D. Zika Virus Infection: after the Pandemic. N Engl J Med. 2019;381(15):1444-57. doi: 10.1056/NEJMra1808246

3. Brasil P, Pereira Jr JP, Moreira ME, Ribeiro Nogueira RM, Damasceno L, Wakimoto M, et al. Zika Virus Infection in pregnant women in Rio de Janeiro. N Engl J Med. 2016;375(24):2321-34. doi: 10.1056/NEJMoa1602412

4. Coronell-Rodríguez W, Arteta-Acosta C, Suárez-Fuentes MA, Burgos-Rolon MC, Rubio-Sotomayor MT, Sarmiento-Gutiérrez M, et al. Infección por virus del Zika en el embarazo, impacto fetal y neonatal. Rev Chil Infectol. 2016;33(6)665-73. doi: 10.4067/S0716-10182016000600009

5. Subissi L, Dub T, Besnard M, Mariteragi-Helle T, Nhan T, Lutringer-Magnin D, et al. Zika virus infection during pregnancy and effects on early childhood development, French Polynesia, 2013-2016. Emerging Infect Dis. 2018;24(10):1850-8. doi 10.3201/eid2410.172079

6. Ministério da Saúde (BR). Atenção ao pré-natal de baixo risco [Internet]. Brasília, DF: Ministério da Saúde; 2013 [cited 2019 Nov 12 ]. 320 p. Available from: http://bvsms.saude.gov.br/bvs/publicacoes/atencao_pre_natal_baixo_risco.pdf

7. Rasmussen SA, Jamieson DJ, Honein MA, Petersen LR. Zika Virus and birth defects: reviewing the evidence for causality. N Engl J Med. 2016;374(20):1981-7. doi: 10.1056/NEJMra1808246

8. Whittemore R, Knafl K. The integrative review: updated methodology. J Adv Nurs. 2005;52(5):546-53. doi: 10.1111/j.1365-2648.2005.03621.x

9. Malta M, Cardoso LO, Bastos Fl, Magnanini MMF, Silva CMFP. Strobe Initiative: grants paragraph communication observational studies. Rev Saúde Pública. 2010;44(3):1-5. doi: 10.1590/S0034-89102010000300021

10. Moher D, Liberati A, Tetzlaff J, Altman DG, and the PG. Preferred reporting items for systematic reviews and meta-analyses: The PRISMA statement. Phys Ther 2009;89(9):873-80. doi: 10.1093/ptj/89.9.873

11. Lage MLC, Carvalho AL, Ventura PA, Taguchi TB, Fernandes AS, Pinho SF, et al. Clinical, neuroimaging, and neurophysiological findings in children with microcephaly related to congenital Zika Virus Infection. Int J Environ Res Public Health. 2019;16(3):309. doi: 10.3390/ijerph16030309

12. Rocha SGMO, Correia LL, Da Cunha AJLA, Rocha HAL, Leite ÁM, Campos JS, et al. Zika Virus Infection and Microcephaly: a case-control study in Brazil. Ann Glob. Health. 2019;85(1):116. doi: 10.5334/aogh.2394

13. Trigueiro SA, Neves BF, Aguiar MSB, Araujo JSS. Correlation between cephalic circumference at birth and ocular alterations in patients with microcephaly potentially associated with Zika Virus infection. Rev Assoc Med Bras. 2019;65(6):909-13. doi 10.1590/1806-9282.65.6.909

14. Baran LCP, Costa MF, Vidal KS, Damico FM, Barboni MTS, Lima DS, et al. Alterations in visual acuity and visual development in infants 1-24 months old either exposed to or infected by Zika virus during gestation, with and without microcephaly. J AAPOS. 2019;23(4):215. doi: 10.1016/j.jaapos.2019.03.005 
15. Einspieler C, Utsch F, Brasil P, Aizawa CYP, Peyton C, Hasue RH, et al. Association of infants exposed to prenatal Zika Virus Infection with their clinical, neurologic, and developmental status evaluated via the general movement assessment tool. JAMA. 2019;2(1):1-13. doi: 10.1001/ jamanetworkopen.2018.7235

16. Ventura PA, Lage MLC, Carvalho AL, Fernandes AS, Taguchi TB, Nascimento-Carvalho CM. Early gross motor development among brazilian children with microcephaly born right after Zika Virus Infection outbreak. J Dev Behav Pediatr. 2019;41(2):134-40. doi: 10.1097/ dbp.0000000000000722

17. Cortes MS, Rivera AM, Yepez M, Guimaraes CV, Yunes ID, Zarutskie A, et al. Clinical assessment and brain findings in a cohort of mothers, fetuses and infants infected with ZIKA virus. Am J Obstet Gynecol. 2018;218(4):440. doi: 10.1016/j.ajog.2018.01.012

18. Tsui I, Moreira MEL, Rossetto JD, Vasconcelos Z, Gaw SL, Neves LM, et al. Eye findings in infants with suspected or confirmed antenatal Zika Virus exposure. Pediatrics. 2018;142(4):e20181104. doi: 10.1542/peds.2018-1104

19. Zin AA, Tsui I, Rossetto JD, Gaw SL, Neves LM, Zin OA, et al. Visual function in infants with antenatal Zika virus exposure. J AAPOS. 2018;22(6):452-6. doi: 10.1016/j.jaapos.2018.07.352

20. Hoen B, Schaub B, Funk AL, Ardillon V, Boullard M, Cabie A, et al. Pregnancy outcomes after ZIKV infection in French territories in the Americas. N Engl J Med. 2018;378(11):985-94. doi: 10.1056/NEJMoa1709481

21. Pinato L, Ribeiro EM, Leite RFP, Lopes TF, Pessoa ALS, Campos LMG, et al. Sleep findings in Brazilian children with congenital Zika syndrome. Sleep. 2018;41(3). doi: 10.1093/sleep/zsy009

22. França TLB, Medeiros WR, Souza NL, Longo E, Pereira SA, Oliveira França TB. Growth and development of children with microcephaly associated with congenital zika virus syndrome in Brazil. Int J Environ Res Public Health. 2018;15(9):1990. doi: 10.3390/ijerph15091990

23. Wheeler AC. Development of infants with congenital zika syndrome: what do we know and what can we expect? Pediatrics. 2018;141:15460. doi: 10.1542/peds.2017-2038D

24. Orofino DHG, Passos SRL, Oliveira RVC, Farias CVB, Leite M, Pone SM, et al. Cardiac findings in infants with in utero exposure to Zika virus- a cross sectional study. PLoS NegI Trop Dis. 2018;12(3):e0006362. doi: 10.1371/journal.pntd.0006362

25. Kikuti M, Cardoso CW, Prates APB, Paploski IAD, Kitron U, Reis MG, et al. Congenital brain abnormalities during a Zika virus epidemic in Salvador, Brazil, April 2015 to July 2016. Euro Surveill. 2018;23(45):1-10. doi: 10.2807/1560-7917.es.2018.23.45.1700757

26. Brady OJ, Osgood-Zimmerman A, Kassebaum NJ, Ray SE, Araujo VEM, Nobrega AA, et al. The association between Zika virus infection and microcephaly in Brazil 2015-2017: an observational analysis of over 4 million births. PLoS Med. 2019;16(3):e1002755. doi: 10.1371/journal. pmed.1002755

27. Noronha L, Zanluca C, Azevedo MLV, Luz KG, Santos CND. Zika virus damages the human placental barrier and presents marked fetal neurotropism. Mem Inst Oswaldo Cruz. 2016;111(5):287-93. doi: 10.1590/0074-02760160085.

28. Broutet N, Krauer F, Riesen M, Khalakdina A, Almiron M, Aldighieri S, et al. Zika Virus as a cause of Neurologic Disorders. N Engl J Med. 2016;374:1506-9. doi: 10.1056/NEJMp1602708

29. Pacheco-Romero J. Zika virus: A new challenge for obstetricians and gynecologists. Rev Peru Ginecol Obstetr [Internet]. 2016 [cited 2019 Nov 16];62(2):219-42. Available from: http://www.scielo.org.pe/scielo.php?script=sci_arttext\&pid=S2304-51322016000200010

30. Petersen LR, Jamieson DJ, Powers AM, Honein MA. Zika Virus. N Engl J Med. 2016;374(16):1552-63. doi: 10.1056/NEJMra1602113 